\title{
HPV 16-associated tumours: IL-12 can repair the absence of cytotoxic and proliferative responses of tumour infiltrating cells after chemotherapy
}

\author{
MARIE INDROVÁ ${ }^{1}$, JANA BIEBLOVÁ ${ }^{1}$, JOANA ROSSOWSKA ${ }^{2}$, PIOTR KUROPKA ${ }^{3}$, \\ ELZBIETA PAJTASZ-PIASECKA ${ }^{2}$, JAN BUBENÍK ${ }^{1}$ and MILAN REINIS ${ }^{1}$ \\ ${ }^{1}$ Institute of Molecular Genetics, Academy of Sciences of the Czech Republic, Prague 4, Czech Republic; \\ ${ }^{2}$ Ludwik Hirszfeld Institute of Immunology and Experimental Therapy, Polish Academy of Sciences, Wroclaw; \\ ${ }^{3}$ Department of Anatomy and Histology, Agriculture Academy of Wroclaw, Poland
}

Received August 19, 2008; Accepted October 6, 2008

DOI: 10.3892/ijo_00000139

\begin{abstract}
We have examined the effect of IL-12-producing cellular vaccines on the cytotoxicity and proliferative potential of $\mathrm{CD} 5^{+}$tumour-infiltrating cells (TIL) in mice carrying syngeneic TC-1 and TC-1/A9 HPV 16-associated tumours after chemotherapy with CBM-4A ifosfamide derivative. The chemotherapy resulted in the decrease of the $\mathrm{CD} 4^{+}$ and $\mathrm{CD} 8^{+} \mathrm{TIL}$, increase of the $\mathrm{Gr}-1^{+} / \mathrm{CD} 11 \mathrm{~b}^{+} \mathrm{TIL}$, no changes in the infiltration with $\mathrm{CD} 4^{+} / \mathrm{CD} 25^{+}$Treg TIL, and decrease of the cytolytic and proliferative potential of the CD45 $\mathrm{TIL}$. Subsequent immunotherapy with the IL-12-producing, genetically modified TC-1 (TC-1-IL-12) cells increased tumour infiltration with $\mathrm{CD}^{+}$and $\mathrm{CD} 4^{+}$cells, decreased the $\mathrm{Gr}-1^{+} / \mathrm{CD} 11 \mathrm{~b}^{+}$cells, and increased the cytolytic and proliferative potential of the CD4 $4^{5+}$ TIL. Taken together, these findings suggest that peritumoral administration of the IL-12producing cellular vaccine can restore the cytolytic potential and inhibit immunosuppressive TIL-dependent mechanisms in the individuals bearing HPV 16-associated tumours, and explain our previously described tumour-inhibitory effects of the vaccine in mice with minimal residual disease after the tumour chemotherapy.
\end{abstract}

Correspondence to: Dr Marie Indrová, Institute of Molecular Genetics, Academy of Sciences of the Czech Republic, v. v. i., Vídenská 1083, 14220 Prague 4, Czech Republic

E-mail: indrova@img.cas.cz

Abbreviations: HPV, human papilloma virus; MHC, major histocompatibility complex; B6, C57BL/6; TIL, tumour-infiltrating lymphocytes; IL-12, interleukin 12; SI, stimulation index; FACS, fluorescence-activated cell sorter; MACS, AutoMACS Pro cell separator-magnetic separation system; MDSC, myeloid-derived suppressor cells; CMRTD, minimal residual tumour disease after cytoreductive chemotherapy

Key words: HPV16, vaccines, tumour-infiltrating cells, cytotoxicity

\section{Introduction}

The presence of tumour-infiltrating lymphocytes (TIL) provides important evidence of anti-tumour reaction in vivo. However, TIL are usually not sufficient for inhibiting tumour growth (reviewed in ref. 1). While the studies of murine and human tumours have shown that TIL are able to recognize tumour antigen and to mediate anti-tumour immunity $(2,3)$, the infiltrating lymphocytes in many cases fail to provide effective tumour resistance and may contribute to tumour progression $(4,5)$.

The functional defectiveness of tumour-infiltrating lymphocytes has been attributed to various mechanisms, including inadequate antigen-presenting and/or costimulatory capacity of tumour cells leading to $\mathrm{T}$ cell ignorance or anergy $(6,7)$, and production of immune suppressive factors by the tumours $(8,9)$. The defectiveness of TIL cells can represent one of the parameters that can correlate with the tumour outcome (10-13). Therefore, understanding the events giving rise to TIL defects, their potential to maintain tumour progression and reparation of these processes, is critical for evaluation of the role of immunity in supporting tumour growth. In addition, such knowledge is critical for determination how to enhance the immunity to obtain a clinically relevant therapeutic effect.

Defective lytic function of $\mathrm{T}$ cells infiltrating human and rodent tumours has been recognized for a long time and numerous preclinical and clinical studies have demonstrated that IL-12 alone or in a combined therapy mediates tumour regression by promoting Th1 responses, by increasing the efficacy of $\mathrm{CD}^{+} \mathrm{T}$ cells, NKT cells, NK cells, antigenpresenting cells and other effectors (14-19). However, the effectiveness of TIL cells in the IL-12 immunotherapy of minimal residual tumour disease remains unknown.

In our previous study (14) we analyzed the effects of interleukin 12 (IL-12) immunotherapy by vaccination with genetically modified, cellular cytokine-producing therapeutic vaccines or with recombinant IL-12 on the treatment of minimal residual tumour disease induced by chemotherapy (CMRTD). The IL-12 treatment was effective against both 
MHC class I-positive and -deficient human papilloma virus 16 (HPV 16)-associated experimental tumours TC-1 and TC-1/ A9. The anti-tumour effects were mediated by a number of different mechanisms, including CD8, CD4, NK11, myeloidderived suppressor Gr-1/CD11b-positive cells, as well as Th1/Th2 cytokines (14), (reviewed in ref. 3 ).

In this communication, we demonstrated the effectiveness of local immunotherapy with tumour vaccine engineered to produce IL-12, using the model of minimal residual tumour disease obtained after cytoreductive chemotherapy (CMRTD), on the distribution and activity of tumour-infiltrating cells. Administration of the IL-12 vaccine led to reappearance of $\mathrm{CD}^{+}$and $\mathrm{CD}^{+}$cells and to a significant increase in the number of $\mathrm{CD} 11 \mathrm{c}^{+}$cells in the tumour nodules. On the other hand, Gr-1/CD11b-positive cells, increased after chemotherapy, were decreased after subsequent immunotherapy. Moreover, $\mathrm{CD} 45^{+}$tumour-infiltrating cells isolated from the treated animals exhibited restored cytotoxic and proliferation potential after short-term in vitro pre-cultivation.

\section{Materials and methods}

Mice. C57BL/6 (B6) male mice, 8-10 weeks old, were obtained from AnLab Co., Prague, Czech Republic.

Cell lines. HPV16-associated, non-metastasizing, MHC class I positive cell line TC-1, immunogenic in syngeneic B6 mice (15) and TC-1/A9, HPV16-associated, non-metastasizing tumour cell line, deficient in MHC class I molecules were used $(22,23)$. The selected cloned subline IL-12-gene modified TC-1-IL-12 (231/clone 15) cells were used for vaccination (Vonka and Sobotková, unpublished data). The transduced cells used for vaccination produced in vitro $40 \mathrm{ng}$ IL-12/1x10 cells/ml medium/48 h (14).

The cell lines were maintained in RPMI-1640 medium supplemented with $10 \%$ foetal calf serum, $2 \mathrm{mM} \mathrm{L-glutamine}$ and antibiotics (complete medium) and were cultured at $37^{\circ} \mathrm{C}$ in a humidified atmosphere with $5 \% \mathrm{CO}_{2}$. For the transduced cell lines, HAT selection medium was used.

Therapeutic protocol. Briefly, a week after induction of CMRTD, the mice were injected with a single dose of IL-12producing, irradiated (150 Gy) TC- 1 -IL-12 cells $\left(1.5 \times 10^{7}\right.$ cells per mouse), in the vicinity of the s.c. tumours (14). Experimental protocols were approved by the Institutional Animal Care Committee of the Institute of Molecular Genetics, Prague.

Flow cytometry. To determine CD45- and CD11c-positive cells, PE anti-mouse CD45 (LCA, LY5) (30F-1) and PE antimouse CD11c (Integrin alpha $a_{x}$ chain) (HL3) were utilized. To determine Gr-1/CD11b-positive cells, FITC rat anti-mouse CD11b (M1/70) and PE anti-mouse Ly-6G (Gr-1) and Ly-6C (Gr-1) (R36-8C5) were used. For detection of CD4- and CD25-positive cells, FITC anti-mouse CD4 (L3T4) (RM4-4) and FITC anti-mouse CD25 (IL-2-Receptor-Chain p55) (PC61) were used. As isotype controls, FITC- and PElabelled antibodies of irrelevant specifity were utilized. All products were purchased from Pharmingen, San Diego, CA. Flow cytometry was performed using an LSR II flow cytometer (BD Biosciences, San Jose, CA).
Preparation of tumour-infiltrating (TIL) cells. Six days after therapy, fragments of the tumour mass (pool of 2-3 tumours) were transferred to the Eppendorf tubes and overlayed with $100 \mu 1$ Collagenase I $(1 \mathrm{mg} / \mathrm{ml}$, Serva Elecrophoresis $\mathrm{GmbH}$, Heidelberg, Germany) plus $1 \mathrm{ml}$ of HBSS buffer with $5 \%$ of FCS and 0.5 U/ml DNase I (Sigma, St. Louis, MO). The tumour tissues were digested for $1 \mathrm{~h}$ at $37^{\circ} \mathrm{C}$ with agitation and the suspension with isolated TIL cells was filtrated through the nylon mesh (the protocol was kindly provided by Dr A. Lapique, Ludwig Institute of Cancer Research, Sao Paulo, Brazil (24).

Magnetic separation (MACS). For MACS separation, the isolated tumour-infiltrating cells were labelled with MACS CD45 MicroBeads Abs according to the manufacturer's instructions, and CD45-positive cells were separated in the AutoMACS Pro cell separator (Miltenyi Biotec, $\mathrm{GnbH}$, Bergisch-Gladbach, Germany).

Histological and immunohistochemical analyses. Tumour tissue cryo-sections, 5-10 $\mu \mathrm{m}$ thick, were fixed in $4 \%$ paraformaldehyde $\left(30 \mathrm{~min}\right.$ at $\left.4^{\circ} \mathrm{C}\right)$, stained with hematoxylin and eosin and examined by light microscopy. For detection of CD4- and CD8-positive cells, tumour cryo-sections were fixed in cold acetone and incubated for $2 \mathrm{~h}$ with rat anti-CD4 or rat anti-CD8 antibodies (BD Pharmingen). The slides were then washed with PBS and incubated $(1 \mathrm{~h})$ with goat antirat antibody conjugated with Alexa Fluor 488 (Molecular Probes), washed and counterstained with PI $(2 \mu \mathrm{g} / \mathrm{ml})$. The fluorophore-labelled tissue sections were analyzed using a Bio-Rad MRC 1024 scanning confocal fluorescence microscope equipped with LaserSharp software. Cryosections from three distinct parts of tumour from each individual mouse were analyzed.

Proliferative response. For priming the proliferative cell response, the TIL cells were cultivated for 3 days in complete RPMI medium with ConA ( $1 \mu \mathrm{g} / \mathrm{ml}$, Pharmacia AB, Uppsala, Sweden) in 96-well round-bottom microtiter plates (Nunc, A/S, Roskilde, Denmark). As positive control, the proliferative response of normal murine spleen cells was used. Twenty hours before harvesting, the cells were labelled with $0.04 \mathrm{MBq}{ }^{3} \mathrm{H}-\mathrm{TdR} /$ well and the uptake of ${ }^{3} \mathrm{H}-\mathrm{TdR}$ was measured in the liquid scintillation system. The stimulation index (SI) was calculated as the ratio of proliferation expressed in $\mathrm{cpm} / \mathrm{min}$ in the experimental (with ConA) and control samples.

${ }^{51} \mathrm{Cr}$ microcytotoxicity assay. The cytolytic activity of the fresh or pre-cultivated $(24 \mathrm{~h}$, in the complete RPMI medium supplemented with $20 \mathrm{U} / \mathrm{ml}$ rIL-2-Proleukin, Chiron B.V., Amsterdam, The Netherlands) was measured. TIL cells were tested using the ${ }^{51} \mathrm{Cr}$ release assay, as described previously $(3,15,21,24) .{ }^{51} \mathrm{Cr}$-labelled tumour targets were mixed with the effector cells in the target-to-effector cell ratio 50:1 in complete RPMI medium supplemented with mercaptoethanol $\left(10^{-5} \mathrm{M}\right)$. The mixtures were incubated in triplicate in 96-well round-bottom microtiter plates (Nunc, A/S). Percent of specific ${ }^{51} \mathrm{Cr}$ release was expressed: [(cpm experimental release - cpm control release) / (cpm maximum release - $\mathrm{cpm}$ 
(a) tumour TC-1

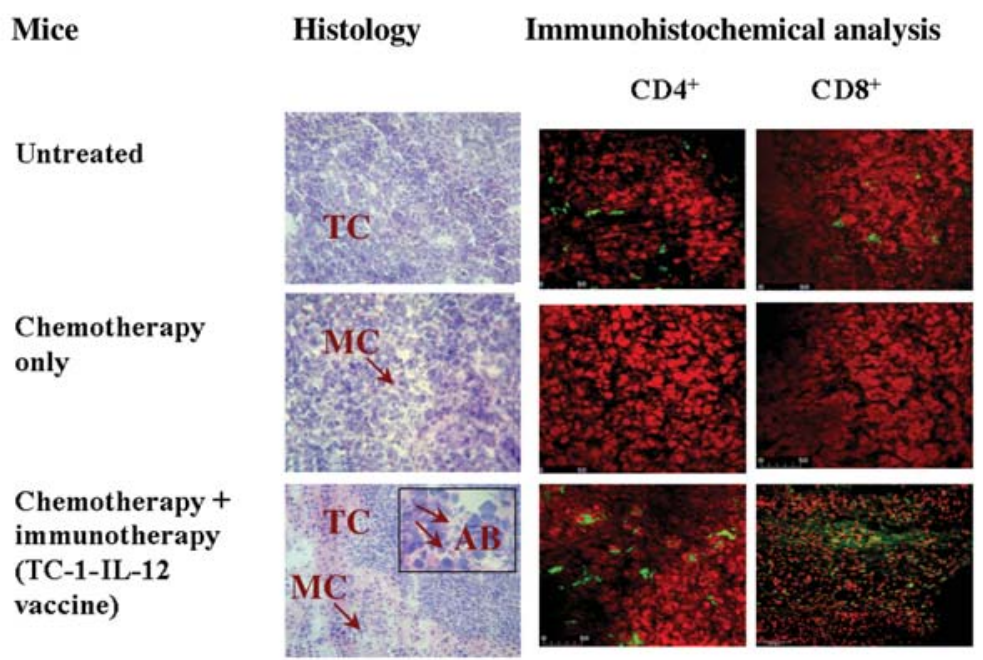

\section{(b) tumour TC-1/A9}

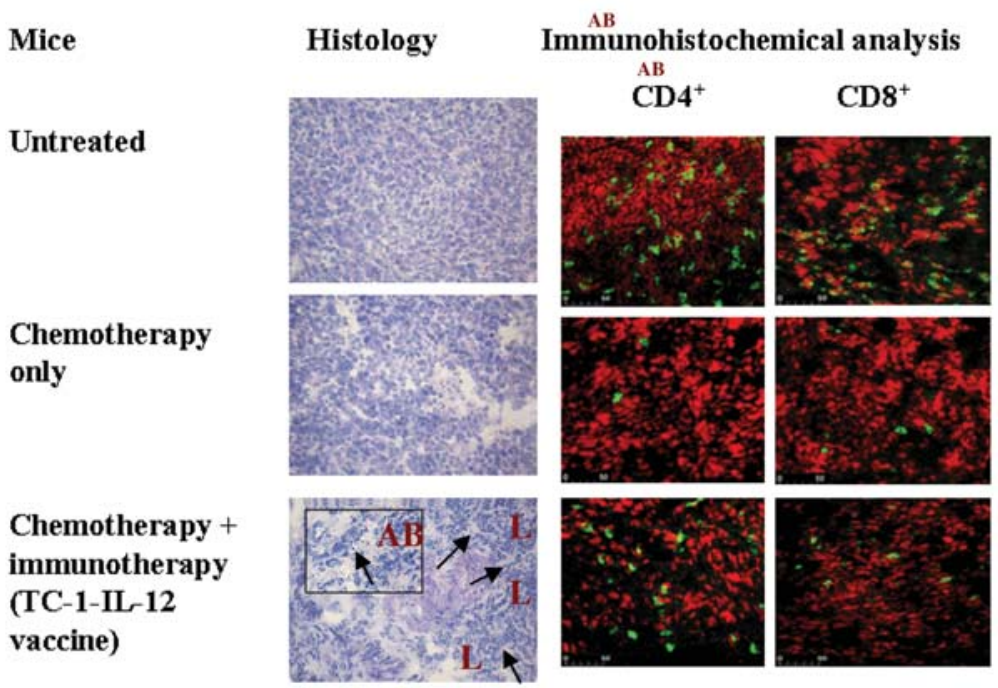

Figure 1. TIL infiltration during tumour growth and therapy. (a) Tumour TC-1, (b) tumour TC-1/A9. Histology: TC, tumour cells; MC, macrophagelike cells, AB, apoptotic bodies; L, lymphocytes. Magnification, 400x or 630x. Immunochemical analysis: red, tumour mass; green, CD4- or CD8positive cells. Representative data from two independent experiments are shown.

control release)] x 100. As target cells, TC-1 and TC-1/A9IFN $\gamma$ (MHC I-positive cells, prepared after 72-h cultivation of MHC I-negative TC-1/A9 cells in the medium supplemented with $50 \mathrm{U} / \mathrm{ml}$ IFN $\gamma$; RD Systems, Minneapolis, MN) were utilized (14).

Statistical analyses. For statistical analyses, Student's t-test from NCSS, Number Cruncher Statistical System (Kaysville, UT) statistical package was used.

\section{Results}

Histological and immunohistological examinations of TC-1 and TC-1/A9 tumour samples. Histological examination of control tumours (both TC-1 and TC-1/A9) revealed that they formed nodules, with very compact tissue structure, closely adjacent tumour cells and poorly developed connective tissue (Fig. 1). Tumour cells of both types possessed features of typical quickly proliferating cells and were characterized by variable size, differently situated (centrally or peripherally) oval nucleus and slightly eosinophil cytoplasm. In the peripheral zone of untreated TC-1 tumour, we observed infiltration of sporadic macrophage-like cells.

Analysis of TC-1 tumours dissected after CBM-4A administration showed that the tumour tissue consisted of densely packed tumour cells with single migratory macrophage-like cells. In addition, the chemotherapy caused a total disappearance of T cells (Fig. 1). After IL-12 and chemotherapy, the increase in the macrophage-like cell number was observed. The administration of CBM-4A followed by TC-1-IL-12 cell 

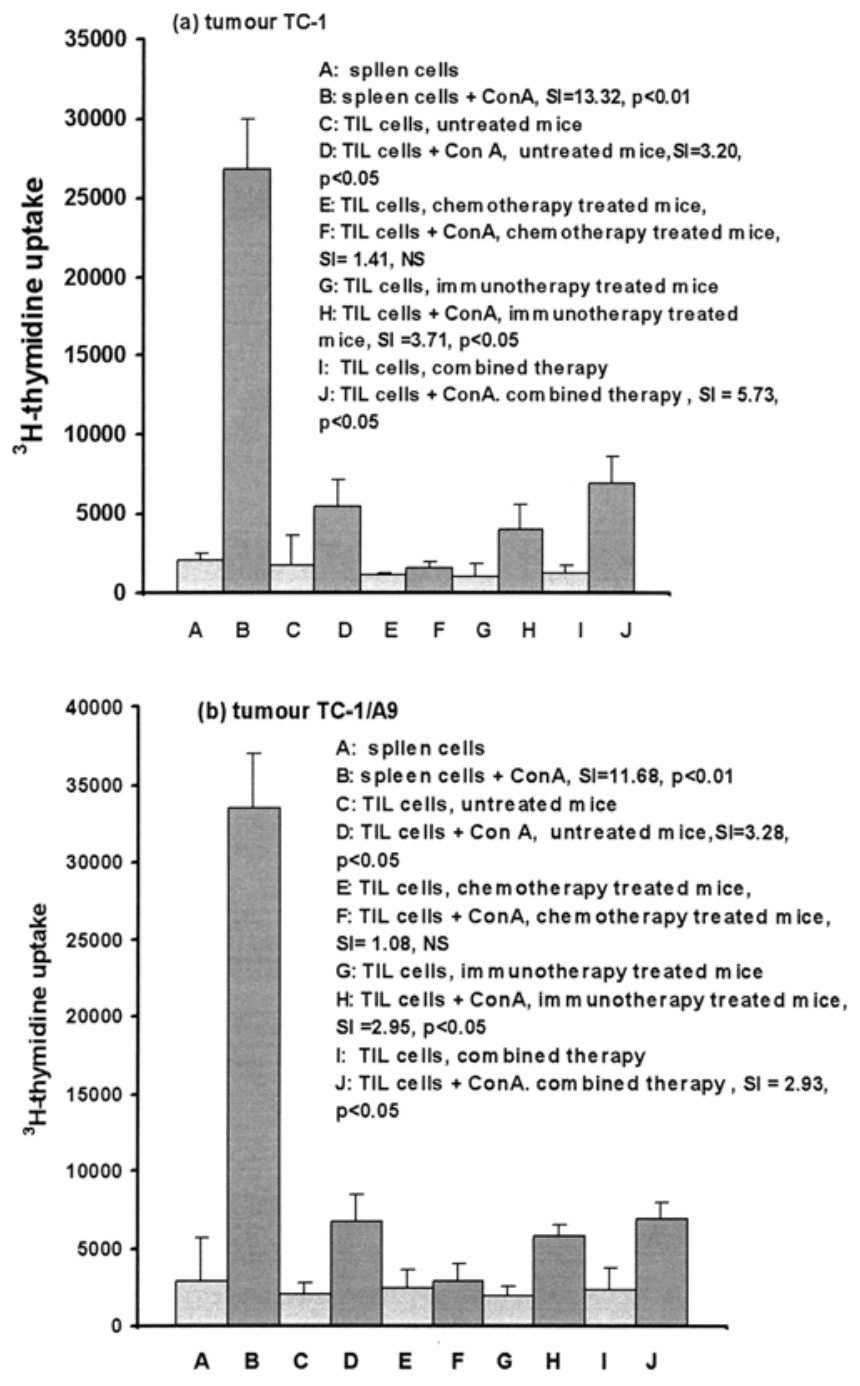

Figure 2. CD $45^{+}$tumour-infiltrating cells during tumour growth and therapy: in vitro proliferation is depressed after chemotherapy and recovered after immunotherapy. $\mathrm{p}<0.01, \mathrm{p}<0.05$, as compared to the non-stimulated cells.

vaccine evoked significant morphological changes in TC-1 tumour tissue. Between loosely arranged tumour cells, there was an abundance of macrophage-like cells which formed focuses and penetrated between tumour cells in the whole tissue (Fig. 1a). In this tissue, the majority of apoptotic cells and necrotic areas were observed, and they were located both in the centre and in the periphery of tumour tissue (Fig. 1a). Moreover, administration of the TC-1-IL-12 cell vaccine after chemotherapy caused renewed influx of $\mathrm{CD}^{+} \mathrm{T}$ cells into the tumour nodules.

In the case of TC-1/A9 tumour tissue, visible morphological changes in the tissue structure occurred just after CBM-4A administration, including loosely arranged tumour cells and few areas with apoptotic cells. Furthermore, although the number of CD4- and CD8-positive T cells in the tissue decreased, they did not disappear, as was noted in TC-1 tumour tissue (Fig. 1b). On the other hand, adjuvant administration of the TC-1-IL-12 vaccine evoked almost complete decay of TC-1/A9 tumour tissue, similarly to TC-1 tumour tissue. TC-1/A9 tumour cells lost their typical morphology and this was accompanied by advanced disintegration of both the peripheral and central part of the tumour nodule, numerous apoptotic bodies and prenecrotic areas surrounded by lymphocytes. Moreover, in the TC-1/A9 tumours, an influx of both CD4- and CD8-positive T cells, but especially CD4+, was observed (Fig. 1b).

Kinetics of the CD11 $\mathrm{c}^{+}, \mathrm{Gr}-\mathrm{1}^{+} / \mathrm{CD} 11 \mathrm{~b}^{+}$and $\mathrm{CD}^{+} / \mathrm{CD} 25^{+}$ TIL during tumour growth and therapy. The FACS analyses of enzymatically digested tumours showed a significant difference in the number of infiltrated $\mathrm{CD} 11 \mathrm{c}^{+}$cells in the TC-1 and TC-1/A9 tumour tissue (Table I). However, in both types of the examined tumours, chemotherapy and also subsequent immunotherapy led to a significant increase in the amount of infiltrating $\mathrm{CD} 11 \mathrm{c}^{+}$cells. The kinetics of infiltrated myeloid-derived suppressor $\mathrm{Gr}-1^{+} / \mathrm{CD}_{11} \mathrm{~b}^{+}$cells was different. In both types of tumours, the amount of $\mathrm{Gr}-1^{+} /$ $\mathrm{CD}_{1} 1 \mathrm{~b}^{+}$cells significantly increased after chemotherapy and decreased again after IL-12 immunotherapy (Table II). On the other hand, the changes in the level of CD4/CD25positive Treg cells were non-significant $(\mathrm{p}>0.05)$ and varied between $0.15-0.75 \%$ of the CD45+ cells (TC-1), or between $0.40-1.95 \%$ of the infiltrating $\mathrm{CD}_{4} 5^{+}$cells (TC-1/A9), respectively.

Proliferative CD45+ TIL responses. To compare the proliferative responses, CD45+ ${ }^{+}$TILs were cultured for three days in the presence of ConA. Both TC-1 (MHC class I ${ }^{+}$) and TC-1/ A9 (MHC class I-) TIL responded significantly to the mito-

Table I. Increase of the percentage of CD11c-positive cells after therapy. ${ }^{\text {a }}$

\begin{tabular}{lcccc}
\hline $\begin{array}{l}\text { Mouse } \\
\text { tumour }\end{array}$ & Untreated & $\begin{array}{c}\text { Chemotherapy } \\
\text { only }\end{array}$ & $\begin{array}{c}\text { Immunotherapy } \\
\text { only }\end{array}$ & $\begin{array}{c}\text { Chemotherapy + immunotherapy } \\
\text { (TC-1-IL-12 vaccine) }\end{array}$ \\
\hline TC-1 & $25.10 \pm 7.00^{\mathrm{b}}$ & $39.47 \pm 11.10^{\mathrm{c}}$ & $20.50 \pm 2.60$ & $52.80 \pm 4.28^{\mathrm{c}}$ \\
TC-1/A9 & $9.15 \pm 7.56$ & $25.17 \pm 12.86^{\mathrm{c}}$ & $37.06 \pm 9.29^{\mathrm{c}}$ & $43.20 \pm 2.00^{\mathrm{c}}$ \\
\hline
\end{tabular}

a\% in $\mathrm{CD} 45^{+}$subpopulation; after MACS separation of $\mathrm{CD} 45^{+}\left(\% \mathrm{CD} 45^{+}\right.$in the mixture of cells obtained after collagenase $\mathrm{I}+\mathrm{DNase}$ treatment prior to MACS separation: $10-30 \%$; the average TIL cell count, $10^{6}$ cells $/ 1 \mathrm{~cm}^{3}$ of tumour mass). ${ }^{b} \mathrm{p}<0.05$, compared to the untreated (TC-1/A9) group; ${ }^{\mathrm{p}}<0.05$, compared to the untreated control groups; the average values were calculated from 5-7 independent FACS determinations. 
Table II. Increase of the percentage of myeloid-derived suppressor Gr-1/CD11b positive cells after chemotherapy accompanied by the decrease after subsequent immunotherapy. ${ }^{\text {a }}$

\begin{tabular}{lcccc}
\hline $\begin{array}{l}\text { Mouse } \\
\text { tumour }\end{array}$ & Untreated & $\begin{array}{c}\text { Chemotherapy } \\
\text { only }\end{array}$ & $\begin{array}{c}\text { Immunotherapy } \\
\text { only }\end{array}$ & $\begin{array}{c}\text { Chemotherapy + immunotherapy } \\
\text { (TC-1-IL-12 vaccine) }\end{array}$ \\
\hline TC-1 & $11.93 \pm 11.90$ & $25.96 \pm 2.67^{\mathrm{b}}$ & $14.50 \pm 5.80$ & $14.02 \pm 2.49$ \\
TC-1/A9 & $9.97 \pm 4.98$ & $27.84 \pm 12.14^{\mathrm{b}}$ & $10.16 \pm 1.27$ & $16.13 \pm 5.07$ \\
\hline
\end{tabular}

a\% in $\mathrm{CD} 45^{+}$subpopulation after MACS separation of $\mathrm{CD} 45^{+}\left(\% \mathrm{CD} 45^{+}\right.$in the mixture of cells obtained after collagenase $\mathrm{I}+\mathrm{DNase}$ treatment prior the MACS separation: $10-30 \%$; the average TIL cell count: $10^{6}$ cells $/ 1 \mathrm{~cm}^{3}$ of tumour mass). ${ }^{b} \mathrm{p}<0.05$, compared to the untreated control groups. The average values were calculated from 5-7 independent FACS determinations.
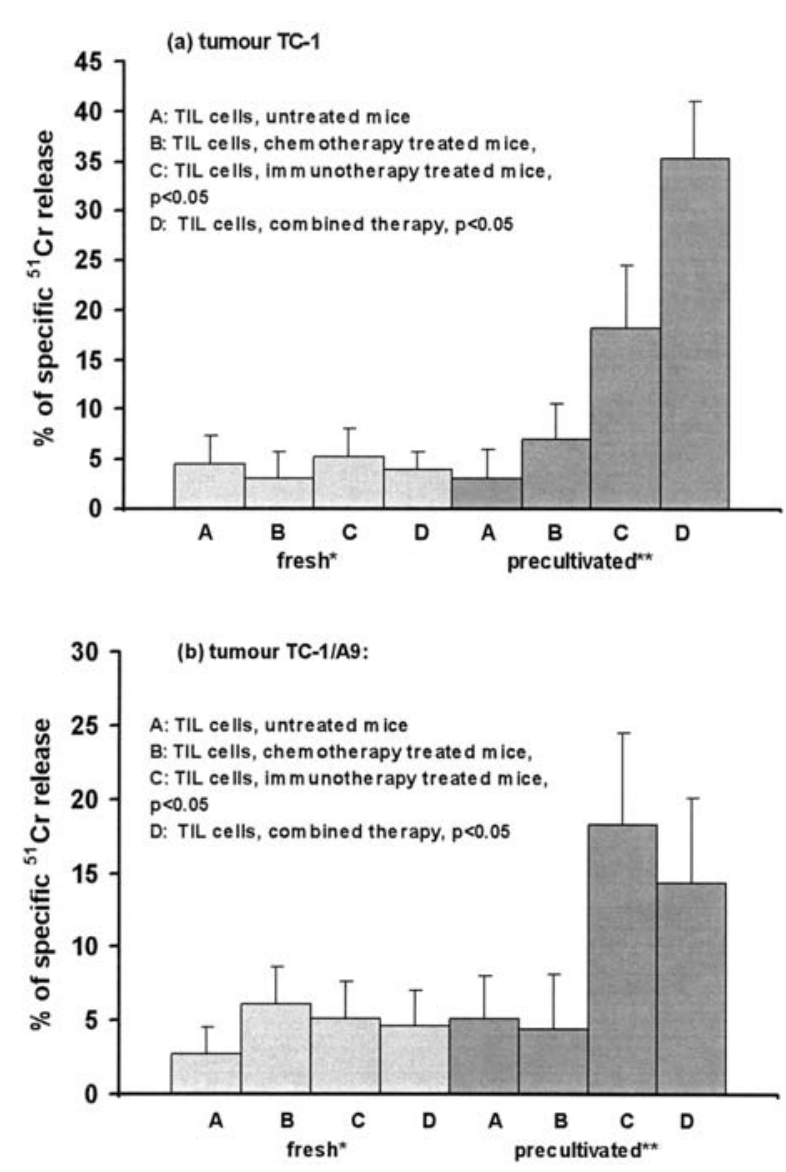

Figure 3. $\mathrm{CD} 45^{+}$tumour-infiltrating cells during tumour growth and therapy: recovery of the cytolysis after short-term culture in vitro. ${ }^{*}$ ex vivo effector cells; **Effector cells after 24-h precultivation in vitro in the medium enriched with $20 \mathrm{U} / \mathrm{ml}$ rIL-2; Effector/target cell ratio: 50:1. (a) Tumour TC-1: C x D, $\mathrm{p}<0.05$ (fresh $\mathrm{x}$ precultivated effectors); $\mathrm{C} \times \mathrm{D}, \mathrm{p}<0.05$ (precultivated effectors). (b) Tumour TC-1/A9: C x D, $\mathrm{p}<0.05$ (fresh $\mathrm{x}$ precultivated effectors); $\mathrm{C} \times \mathrm{D}, \mathrm{p}>0.05$, not significant (precultivated effectors).

genic stimulus of ConA. This response was decreased after chemotherapy and restored again after administration of the IL-12 vaccine (Fig. 2). As a control, the proliferative responses of normal splenocytes were assessed (Fig. 2).

Cytolytic activity of CD45+ TILs. Freshly isolated TIL cells did not exhibit any significant cytotoxic activity (Fig. 3).
However, after short in vitro precultivation in the presence of threshold doses of IL-2 $(20 \mathrm{U} / \mathrm{ml})$ a restored cytotoxic potential of TIL cells in both growing tumours, TC-1 and TC-1/A9, treated with IL-12 immunotherapy was found. Cytotoxic tumour-infiltrating $\mathrm{CD} 45^{+}$cells, detectable in the ${ }^{51} \mathrm{Cr}$ microcytotoxicity assay, were found after immunotherapy with genetically modified, IL-12-producing cellular vaccine, as well as after the combined chemo-immunotherapy in both, TC-1 and TC-1/A9 tumours. Moreover, the combined chemo-immunotherapy of the TC-1 tumours, but not that of the TC-1/A9 tumours, augmented significantly the cytotoxic potential of precultivated CD45 ${ }^{+}$TIL. No cytotoxic effectors were detected after the cytostatic treatment only (Fig. 3).

\section{Discussion}

The efficacy of local immunotherapy with tumour vaccines engineered to produce IL-12 in the model of minimal residual tumour disease after cytoreductive chemotherapy (CMRTD) is based on the activation of a broad spectrum of different immunological mechanisms. In this study, we have focused on the analysis of distribution and activity of tumour-infiltrating cells using the model of subsequent therapy of CMRTD with IL-12-producing vaccines of HPV 16-associated murine tumours.

Cyclophosphamide and its derivatives are known as drugs with a broad spectrum of effects in the immune system. The most essential effects are the decrease of the activity of cytotoxic lymphocytes and modulation of cell lineages with immunosuppressive functions, i.e. Treg and myeloid-derived suppressor cells $(25,26)$. While the effects on the Treg cells can stimulate the antitumour immunity, accumulation of MDSC is known to serve as an immunosuppressive mechanism (27). The accumulation of MDSC in the tumour after chemotherapy might cause the weak cytotoxic effect of TIL cells and loss of proliferative responses to mitogens. Moreover, restoration of cytotoxic and proliferative responses after IL-12 immunotherapy correlates with the decrease of tumour-infiltrated MDSC. These results are in agreement with the findings of Umenura et al (28) and Saio et al (29), who reported that the tumour-infiltrating MDSC strongly suppress $\mathrm{T}$ cell proliferation and the growth of activated $\mathrm{CD}^{+}$cells. On the other hand, we found a very low percentage of the CD4/CD25-positive Treg cells, which 
remained unchanged during the growth and therapy of tumours. These findings correlate with our previous results (15) obtained in the same model, when similar dynamics of MDSC and Treg in the spleens of cured mice after chemotherapy and combined chemo-immunotherapy with IL-12producing vaccines was found.

The increase in the percentage of infiltrated CD11cpositive cells after chemotherapy as well as after combined chemo-immunotherapy corresponds with the results obtained in the immunohistochemical analyses. In general, the increase of CD11c-positive TIL cells is associated with a better outcome in a variety of tumours (28). The level of infiltration in both our cell lines, TC-1 and TC-1/A9, was different. The TC-1/A9 tumour was characterized by higher infiltration of leukocytes, but this increased infiltration was not correlated with the cytotoxic effect of these cells. This finding could probably be connected with the MHC-negative status of the TC-1/A9 cells. A similar observation was published by Preynat-Seauve et al (9), who found different tumour infiltration with immunocompetent dendritic cells in distinct murine melanoma tumours. These findings suggest that the tumour milieu varies in its capacity to mobilize immunocompetent cells. The kinetics of CD8- and CD4positive cells also corresponded with the treatment of tumours. The CD8- and CD4-positive cells disappeared after chemotherapy and reappeared together with the cytotoxic activity after subsequent IL-12 vaccine therapy.

Taken collectively, the results imply that the treatment of CMRTD with genetically IL-12-modified tumour cells can restore and potentiate the mechanisms of tumour resistance and the appearance of TIL cells.

\section{Acknowledgements}

This work was supported by grant No. 301/06/0774 from the Grant Agency of the Czech Republic and in part by grant No. AVOZ50520514 awarded by the AS CR, by grant of the Clinigene project EU-FP6-NOE No. 018933, by grant of the Polish Ministry of Science and Higher Education N N401 235334, and by the Joint Project under the Agreement of Scientific Cooperation between PAN and AS CR (20062008). The authors are grateful to Dr Michal Smahel for TC-1/A9, TC-1-IL-12 cells, to Mrs. Renáta Turecková and Marie Malecková for skilful technical assistance, and to Dr Sárka Takácová for editorial help.

\section{References}

1. Yu R, Fujoi K, Tahara H, Araki Y and Yamamoto K: Clonal dynamics of tumour-infiltrating lymphocytes. Eur J Immunol 35: 1754-1763, 2005

2. Bubeník J, Zeuthen J, Indrová M, Bubeníková D and Símová J: Kimetics and function of peritoneal exudate cells during local IL-2 gene therapy of cancer. Int J Oncol 4: 13-16, 1994.

3. Bubenik J: Genetically modified cellular vaccines for therapy of human papilloma virus type 16 (HPV 16)-associated tumours (review). Curr Cancer Drug Targets 8: 180-186, 2008.

4. Koneru M, Schaer D, Monu N, Ayala A and Frey AB: Defective proximal TCR signaling inhibits $\mathrm{CD} 8^{+}$tumour-infiltrating lymphocyte lytic function. J Immunol 177: 1830-1840, 2005

5. Prins RM, Incardona F, Lau R, Lee P, Claus S, Zhang W Black KL and Wheeler CJ: Characterization of defective CD4CD8- T cells in murine tumors generated independent of antigen specificity. J Immunol 172: 1602-1611, 2004.
6. Ochsenbein AF, Klenerman P, Karrer U, Ludewig B, Pericin M, Hengartner $\mathrm{H}$ and Zinkernagel RM: Immune surveillance against a solid tumor fails because of immunological ignorance. Proc Natl Acad Sci USA 96: 2233-2238, 1999.

7. Staveley-O'Carroll K, Sotomayor E, Montgomer J, Borrello I, Hwang L, Fein S, Pardoll D and Levitsky H: Induction of antigen-specific T cell anergy: an early event in the course of tumor progression. Proc Natl Acad Sci USA 95: 1178-1183, 1998.

8. Dumontet C, Rebbaa A, Bienvenu J and Portoukalian J: Inhibition of immune cell proliferation and cytokine production by lipoprotein-bound gangliosides. Cancer Immunol Immunother 38: 311-316, 1994

9. Preynat-Seauve O, Schuler P, Contassot E, Beermann F, Huard B and French LE: Tumor-infiltrating dendritic cells are potent antigen-presenting cells able to activate $\mathrm{T}$ cells and mediate tumor rejection. J Immunol 176: 61-67, 2006.

10. Bukowski RM, Rayman P, Uzzo R, et al: Signal transduction abnormalities in $\mathrm{T}$ lymphocytes from patients with advanced renal carcinoma: clinical relevance and effects of cytokine therapy. Clin Cancer Res 4: 2337-2347, 1988.

11. Kuss I, Saito T, Johnson JT and Whiteside TL: Clinical significance of decreased chain expression in peripheral blood lymphocytes of patients with head and neck cancer. Clin Cancer Res 5: 329-334, 1999.

12. Morford LA, Elliott LH, Carlson SL, Brooks WH and Roszman TL: $\mathrm{T}$ cell receptor-mediated signaling is defective in T cells obtained from patients with primary intracranial tumors. J Immunol 159: 4415-4442, 1997.

13. Reichert TE. Day R, Wagner EM and Whiteside TL: Absent or low expression of the chain in $\mathrm{T}$ cells at the tumor site correlates with poor survival in patients with oral carcinoma. Cancer Res 58: 5344-5347, 1998.

14. Indrová M, Bieblová J, Jandlová T, Vonka V, Pajtasz-Piasecka E and Reinis M: Chemotherapy, IL-12 gene therapy and combined adjuvant therapy of HPV16-associated MHC class I-proficient and -deficient tumours. Int J Oncol 28: 253-259, 2006.

15. Indrová M, Bieblová J, Bubeník J and Reinis M: IL-12 immunotherapy of minimal residual disease in murine models of HPV16-associated tumours: induction of immune responses, cytokine production and kinetics of immune cell subsets. Int J Oncol 32: 499-507, 2008.

16. Kilinc MO, Aulakh KS, Nair RE, Jones SA, Alard P, Kosiewicz MM and Egilmez NK: Reversing tumor immune suppression with intratumoral IL-12: activation of tumorassociated $\mathrm{T}$ effector/memory cells, induction of $\mathrm{T}$ suppressor apoptosis, and infiltration of $\mathrm{CD} 8^{+} \mathrm{T}$ effectors. J Immunol 177: 6962-6973, 2006.

17. Knutson KL and Disis ML: Tumor antigen-specific $\mathrm{T}$ helper cells in cancer immunity and immunotherapy (review). Cancer Immunol Immunother 54: 721-728, 2005.

18. Portielje JE, Gratama JW, van Ojik HH, Stoter G and Kruit WH: IL-12: a promising adjuvant for cancer vaccination (review). Cancer Immunol Immunother 52: 133-144, 2003.

19. Walzer T, Dalod M, Robins SH and Zitvogel L: Naturalkiller cells and dendritic cells: 'l' union fait la force' (review). Blood 104: 2252-2258, 2005.

20. Lin KY, Guarnieri FG, Staveley-O'Carroll KF, Levitsky HJ, August JT, Pardoll DM and Wu TC: Treatment of established tumors with a novel vaccine that enhances major histocompatibility class II presentation of tumor antigen. Cancer Res 56: 21-26, 1996.

21. Mikysková R, Bubeník J, Vonka V, Smahel M, Indrová M, Bieblová J, Simová J and Jandlová T: Immune escape phenotype of HPV16-associated tumours: MHC class I expression changes during progression and therapy. Int J Oncol 26: 521-527, 2005 .

22. Smahel M, Síma P, Ludvíková V, Marinov I, Pokorná D and Vonka V: Immunisation with modified HPV16 E7 genes against mouse oncogenic TC-1 cell sublines with downregulated expression of MHC class I molecules. Vaccine 21: 1125-1136, 2003.

23. Lahound M, Wrenec D, Boyd RL and Shortman K: Characterization of thymic nurse cell lymphocytes, using an improved procedure for nurse cell isolation. Dev Immunol 3: 103-112, 1993.

24. Indrová M, Reinis M, Bubeník J, Jandlová T, Bieblové J, Vonka V and Velek J: Immunogenicity of dendritic cell-based HPV16 E6/E7 peptide vaccines: CTL activation and protective effects. Folia Biol (Praha) 50: 184-193, 2004. 
25. Angulo I, de las Heras FG, Garcia-Bustos JF, Gargallo D Munoz-Fernandez MA and Fresno M: Nitric oxide-producing CD11b(+)Ly-6G(Gr-1)(+)CD31(ER-MP12)(+) cells in the spleen of cyclophosphamide-treated mice: implications for T-cell responses in immunosuppressed mice. Blood 95: 212-220, 2000

26. Salem ML, Kadima AN, El-Naggar SA, Rubinstein MP, Chen Y, Gillanders WE and Cole DJ: Defining the ability of cyclophosphamide preconditioning to enhance the antigenspecific $\mathrm{CD} 8^{+} \mathrm{T}$-cell response to peptide vaccination: creation of abeneficial host microenvironment involving type I IFNs and myeloid cells. J Immunother 30: 40-53, 2007.

27. Huang B, Pan PY, Li Q, Sato AI, Levy DE, Bromberg J, Divino $\mathrm{CM}$ and $\mathrm{Chen} \mathrm{SH}$ : Gr- $1^{+} \mathrm{CD} 115^{+}$immature myeloid suppressor cells mediate the development of tumor-induced $\mathrm{T}$ regulatory cells and T-cell anergy in tumor-bearing host. Cancer Res 66: 1123-1131, 2006.
28. Umemura N, Saio M, Suwa T, Kitoh Y, Bai J, Nonaka K Ouyang GF, Okada M, Balazs M, Adany R, Shibata T and Takami T: Tumor-infiltrating myeloid-derived suppressor cells are pleiotropic-inflamed monocytes/macrophages that bear M1- and M2-type characteristics. J Leukoc Biol 83: 1136-1144, 2008.

29. Saio M, Radoja, S, Marino M and Frey AB: Tumor-infiltrating macrophages induce apoptosis in activated CD8(+) T cells by a mechanism requiring cell contact and mediated by both the cell-associated form of TNF and nitric oxide. J Immunol 167: 5583-5593, 2001.

30. Shurin MR, Shurin GV, Lokshin A, Yurkovetsky ZR, Gutkin DW, Chatta G, Zhong H, Han B and Ferris R: Intratumoral cytokines/ chemokines/growth factors and tumor infiltrating dendritic cells: friends or enemies? (review). Cancer Metastasis Rev 25: 333-356, 2006. 